УДК 343.21

DOI

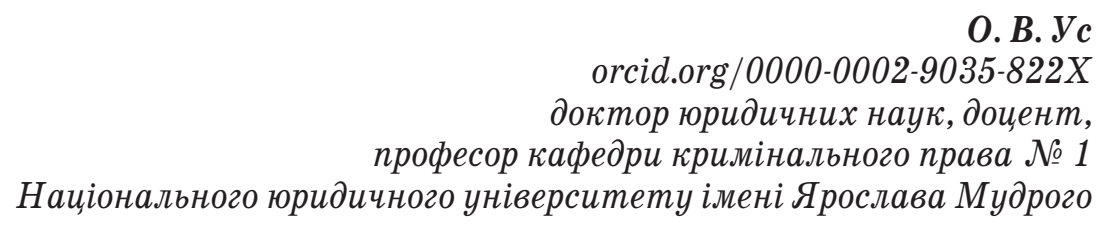

\title{
АЛГОРИТМИ КВАЛІФІКАЦІЇ У КРИМІНАЛЬНОМУ ПРАВІ
}

Кваліфікація у кримінальному праві як логічна, розумово-пізнавальна й інтелектуально-вольова діяльність здійснюється в декілька етапів, на підставі алгоритмів, з урахуванням правил, позначається відповідною формулою. Етапи, алгоритми, правила та формула кваліфікації у кримінальному праві є взаємопов'язаними та взаємозалежними їі складовими частинами. Водночас неправильно їх ототожнювати з методологічного погляду. Розмежування етапів, алгоритмів, правил та формули кваліфікації у кримінальному праві лежить у площині їхнього функціонального призначення та системно-структурного утворення кваліфікації.

Оскільки кваліфікація являє розумовий, логічний, інтелектуально-вольовий процес пізнання й оцінки кримінального юридичного факту, зіставлення його зі складом кримінально значущого діяння, це надає можливість її алгоритмізації. Застосування алгоритмічного підходу у кваліфікації, хоча й не зумовлює абсолютної гарантії досягнення істини, проте суттєво підвищує надійність її результату, оскільки недооцінка використання точних кількісних методик під час кваліфікації неприпустима.

Відповідно до «Академічного тлумачного словника української мови», алгоритм - це система правил виконання обчислювального процесу, що приводить до розв' язання певного класу задач після скінченного числа операцій [1]. "Алгоритм» походить від латинського слова algorismus - латинська транслітерація імені арабського вченого IX ст. Мухамеда бен Муси аль-Хорезмі [2], являє собою набір послідовних операцій, що дозволяють вирішувати будь-яку задачу певного типу.

Алгоритм - точний припис, що визначає процес перетворення первинних (початкових) даних на кінцевий результат [3]. Кожен алгоритм характеризується наявністю вхідних даних, тобто величин, заданих до початку алгоритмічного процесу, або значення яких визначається під час роботи алгоритму, та вихідних даних, тобто величин, що мають досить визначений зв'язок із вхідними даними та характеризують кінцевий результат алгоритмічного процесу. Робота кожного алгоритму відбувається шляхом виконання послідовності відповідних дій, операцій. Такі дії в науці дістали назву «кроки», а процес їх виконання - «алгоритмічний процес» .
Процес алгоритмізації дозволяє поряд із числовими алгоритмами розробляти алгоритми для нечислових об'єктів, наприклад для логічних виражень та лінгвістичних перемінних, послідовностей довільних символів тощо. Пов'язано це 3 розвитком математики, насамперед так званої нечіткої математики, що відіграє головну роль у теорії ухвалення рішень [4, с. 170]. Нечітка математика є засобом подолання розриву між математичними моделями, методами, судженнями та принципами вирішення завдань у галузях, що відрізняються низьким рівнем формалізації, до яких належить і юриспруденція. В основі нечіткої математики покладено поняття нечіткої множинності, що передбачає використання як основних елементів не чисел, а лінгвістичних перемінних, прикладами яких можуть бути поняття такого типу, як «ступінь суспільної небезпеки», «ступінь суворості» тощо [5, с. 4].

Алгоритл кваліфікації у кримінальному праві - це система дій, модель, програма виконання в певному порядку відповідної послідовності операцій, що визначають процес пошуку результату (результативність), а саме приводять до вирішення завдання кримінально-правової оцінки вчиненого - встановлення складу кримінально значущого діяння, передбаченого кримінальним законом (кримінальне правопорушення; діяння, що не є кримінально протиправним, проте має кримінально-правове значення; посткримінальна поведінка особи) [6, с. 168].

Кваліфікація у кримінальному праві полягає у виконанні відповідного завдання (задача) - кримінально-правовій оцінці вчиненого (кримінальний юридичний факт). Алгоритм кваліфікації у кримінальному праві забезпечує послідовність, порядок, логічність процесу пізнання та вирішення цього завдання. Алгоритм вирішення кваліфікаційного завдання можна уявити у виді послідовних, поступових операцій щодо пошуку відповіді на поставлені питання: «отримання інформаціі» - «побудова варіантів запитань / початкових кваліфікаційних версій» - «надання відповіді на запитання, тобто отримання більш конкретизованої інформації» - «побудова варіантів запитань 3 урахуванням більш конкретизованої інформації / подальших кваліфікаційних версій" - тощо «отримання остаточної необхідної інформації» 
- «ухвалення рішення». Складність завдання зумовлює кількість запитань та кваліфікаційних версій. Для оцінки складності використовують прийнятий у психології поділ завдань на три типи: а) стереотипні (мають рішення та виконуються механічно); б) діагностичні (вимагають вибору оптимального варіанта рішення з декількох, що вже мають місце, потребують його корегування); в) евристичні (передбачають застосування творчого підходу, оскільки не мають аналога). 3 позиції теорії інформації можна зазначити, що стереотипні завдання мають жорсткий алгоритм; діагностичні - адаптований; евристичні є неалгоритмізованими [4, с. 169]. Можна зауважити, що здійснення кваліфікації насамперед полягає у вирішенні діагностичного завдання. Водночас не варто виключати й наявність стереотипних i евристичних завдань. Такий алгоритм буде мати адаптивні особливості, оскільки буде конкретизуватися у процесі здійснення. Зазначене є ще одним з аргументів щодо можливості й доцільності алгоритмізації кримінально-правової оцінки вчиненого.

Для вирішення кваліфікаційного завдання алгоритмічний процес як система поступових взаємозумовлених та взаємопов'язаних операцій потребує поступового надання відповідей на питання: «так» чи «ні», що зумовлює подальшу логіку побудови запитань і розв'язання завдання щодо кримінально-правової оцінки кримінально значущого діяння. Наприклад, установлено, що в учиненні суспільно небезпечного діяння брали участь декілька осіб. Алгоритм кваліфікації може бути такий: 1) необхідно дати відповідь на такі запитання: а) усі ці особи є суб'єктами? б) одна із цих осіб є суб'єктом? в) жодна із цих осіб не є суб'єктом кримінального правопорушення?; 2) якщо всі ці особи є суб'єктами, то необхідно встановити, чи має місце: а) співучасть у кримінальному правопорушенні; б) необережне співзавдання або в) причетність до кримінального правопорушення. Для цього треба з'ясувати, 3 якою формою вини вчинено кримінальне правопорушення. Якщо вчинено необережне кримінальне правопорушення, то можна ставити питання про необережне співзавдання. Якщо кримінальне правопорушення скоєно умисно, то варто з'ясувати, на якій стадії його вчинення «об’єдналися» суб'єкти: якщо спільні зусилля суб'єктів мали місце під час готування до кримінального правопорушення або замаху на кримінальне правопорушення, то має місце співучасть у кримінальному правопорушенні; якщо один суб'єкт приєднався до іншого на стадії закінченого кримінального правопорушення, то має місце причетність до кримінального правопорушення тощо; 3) якщо лише одна із цих осіб є суб'єктом кримінального правопорушення, то доцільно аналізувати опосередковане завдання шкоди; 4) якщо жодна із цих осіб не є суб'єктом кримінального правопорушення, доцільно оцінювати вчинене як суспільно небезпечне діяння, скоєне особою, яка не є суб'єктом кримінального правопорушення, тощо.

Окрім зазначеного, алгоритм кваліфікації у кримінальному праві характеризується низкою особливостей, як-от: а) скінченність - алгоритм завжди має завершуватись після виконання скінченної кількості алгоритмічних кроків отриманням відповідного результату - наданням кримінально-правової оцінки вчиненому кримінально значущому діянню; б) дискретність - алгоритмічний процес може бути поділений на окремі дії, операції (алгоритмічні кроки), кожна з яких є послідовним етапом для досягнення відповідного завдання (отримання результату) кваліфікації у кримінальному праві; в) визначеність - кожен крок алгоритму має бути точно, чітко та недвозначно визначений для певного випадку; виконання алгоритмічних кроків відбувається єдиним способом та приводить до однакового результату для однакових / схожих, подібних вхідних даних; г) масовість (загальність) - алгоритм кваліфікації у кримінальному праві повинен забезпечувати розв'язання будь-якого завдання з категорії однотипних завдань за будь-якими вхідними даними, що належать до сфери застосування алгоритму.

У науковій літературі слушно зазначається, що під час здійснення кваліфікації легко стати жертвою психічних особливостей мисленнєвого процесу, коли суб'єкт кваліфікації, побачивши щось суб'єктивно типове, у результаті виниклого в його головному мозку осередку збудження, не звернув уваги на факти, що перебували «на поверхні» і мали кримінально-правове значення [7, с. 93]. Власне використання алгоритму пізнання та кримінально-правової оцінки вчиненого допоможе усунути такі можливі вади. Навіть більше, процес пізнання й оцінки насамперед здійснюється на підсвідомості, а вже потім обгрунтовується, ухвалюється відповідне рішення. У науковій літературі навіть висловлена думка, що відповідні етапи (стадії) кваліфікації можуть не усвідомлюватися суб'єктом кваліфікації, проте алгоритмічний процес кваліфікації завжди відображається у свідомості такого суб'єкта [7, с. 71].

Алгоритми становлять важливу складову частину кваліфікації у кримінальному праві, зокрема: а) визначають процес, систему операцій, дій щодо кримінально-правової оцінки кримінального юридичного факту; б) дозволяють економити розумову працю, уникати зайвих дій / кроків в обробленні інформації під час здійснення кримінально-правової оцінки та мінімізувати можливість помилкового розв'язання кваліфікаційних завдань; в) зумовлюють можливість діджиталізації вирішення кваліфікаційних завдань; 
г) є засобом дослідження та вирішення нових проблем як кваліфікації у кримінальному праві, так і кримінально-правового регулювання; г) дозволяють описувати складні процеси як кримінально-правового регулювання, так і кваліфікації у кримінальному праві.

У кримінально-правовій доктрині висловлена позиція, відповідно до якої алгоритм та етапи кваліфікації деякою мірою є тотожними [8, с. 40]. 3 урахуванням того, що етапи й алгоритм $є$ елементами системи кваліфікації у кримінальному праві, уважаємо за доцільне зауважити їні відмінності: 1) етапи підтверджують, що кваліфікація у кримінальному праві - це процес, діяльність, що характеризується набором відповідних логічних, розумово-пізнавальних операцій, які об’єднуються в таких основних напрямах: 3 одного боку, під час кримінально-правового оцінювання аналізується вчинене особою діяння, тобто фактична підстава кваліфікації («отримання інформації» (вхід даних)), а із другого - склад кримінально значущого діяння, передбачений кримінальним законом, тобто юридична підстава кваліфікації ( «ухвалення рішення» (вихід даних)); 2) етапи кваліфікації характеризуються сукупністю відносно відокремлених, пов'язаних один з одним періодів кримінально-правової оцінки щодо встановлення тотожності кримінального юридичного факту складу кримінально значущого діяння та закріплення результатів оцінки у правозастосовному акті, водночас алгоритм кваліфікації характеризується системою поступових взаємозумовлених та взаємопов'язаних операцій щодо поступового надання відповідей на питання: «так» чи «ні», що зумовлює подальшу логіку побудови запитань і розв'язання завдання щодо кримінально-правової оцінки кримінально значущого діяння; 3) етапи підтверджують, що кваліфікація - це процес, логічна, розумово-пізнавальна діяльність, тоді як алгоритм забезпечує послідовність,порядок, логічністьпроцесупізнання; 4) етапи кваліфікації мають природний (закономірний) характер, а алгоритм кваліфікації - це штучно створена наукова конструкція; 5) якщо алгоритм кваліфікації зумовлений видом кваліфікації / видом кримінально значущого діяння, то етапи кваліфікації характерні для всіх її видів незалежно від об’єкта кваліфікації; 6) існування та проходження етапів кваліфікації суб'єкт не завжди усвідомлює, може констатувати наявність тапів після завершення процесу кваліфікації, тоді як кроки алгоритмічного процесу усвідомлюються суб'єктом кваліфікації, він завжди передбачає попередню заданість; 7) виділення етапів кваліфікації має дещо умовний характер. Суб’єкт кваліфікації не завжди у процесі пізнання може їх чітко відокремити, усвідомлювати кожен із таких етапів, на відміну від алгоритму пізнання, оскільки останній передбачає послідовне надання відповідей на пов'язані запитання щодо оцінки кримінального юридичного факту.

У науковій літературі також висловлюється думка, відповідно до якої алгоритми та правила кваліфікації є тотожними поняттями. Уважаємо за доцільне зазначити, що, на наш погляд, правила кваліфікації у кримінальному праві - це нормативні приписи, загальновизнані доктринальні положення та роз'яснення вищої судової інстанції, якими має керуватися суб'єкт кваліфікації під час обрання кримінально-правової норми для кримінально-правової оцінки вчиненого кримінально значущого діяння [9, с. 34]. Ці правила визначають як загальні, так і спеціальні вимоги, що ставляться до застосування кримінального закону під час вирішення питання про наявність або відсутність юридичної підстави кваліфікації кримінально значущого діяння. Правило кваліфікації - положення, яке регламентує закономірність кримінально-правової оцінки, усталене співвідношення фактичного та юридичного у вчиненому, зрештою, дає відповідь на питання - яка кримінально-правова норма передбачає вчинене діяння. Функціональним призначенням правил кваліфікації є обгрунтоване, правильне, ефективне, одностайне застосування кримінально-правових норм під час здійснення кримінально-правової оцінки кримінально значущого діяння.

Правила кваліфікації застосовуються, якщо вчиненому надано відповідну кримінально-правову оцінку. Правила кваліфікації повинні віднайти законодавчу реглламентацію, що зумовить єдність підходів кримінально-правової оцінки, її ефективність, результативність та конкретизованість із метою виконання завдань кримінально-правового впливу. Наявність у кримінальному законі правил кваліфікації сформує в механізмі кримінально-правового регулювання єдиний підхід щодо кримінально-правової оцінки кримінально значущих діянь з урахуванням як їхніх загальних характеристик, так і специфічних властивостей, притаманних конкретному випадку. Правила кваліфікації виконують властиву їм забезпечувальну функцію, оскільки забезпечують єдині підходи у слідчо-судовій практиці щодо кримінально-правової оцінки вчиненого, визначеність та достовірність результатів такої кваліфікації, мінімізацію ризиків неправильної кваліфікації, формалізацію процесу кваліфікації, мінімізацію розсуду правозастосувача у процесі кваліфікації тощо.

Що стосується загальних вимог побудови алгоритму кваліфікації у кримінальному праві, уважаємо за доцільне зазначити таке:

1. Кваліфікація насамперед зумовлюється кримінальним законом / кримінально-правовим регулюванням. 3 одного боку, кваліфікація реагує на зміни кримінально-правового регулювання, a iз другого - алгоритми та 
правила кваліфікації повинні бути такими, щоб у разі порушення системності кримінально-правового регулювання, наявності його прогалин та неузгодженостей, його надмірності чи недостатності такі алгоритми та правила забезпечували правильну кримінально-правову оцінку вчиненого.

2. Алгоритм базується, будується на правилах логіки і формально-логічних законах, методах аналізу, синтезу, розпізнання; характеризується скінченністю, дискретністю, визначеністю, однозначністю, результативністю, масовістю / загальністю; повинен бути побудований таким чином, щоб він не міг призводити до неправильного рішення.

3. Алгоритм має поступовий, послідовний, покроковий характер вирішення завдання, характеризується системою взаємопов'язаних та взаємозумовлювальних логіко-пізнавальних розумово-аналітичних операцій.

4. За формою алгоритм може бути лінійним (покроковий, такий, що передбачає певний ланцюг кроків) чи розгалуженим (являє собою низку питань, що потребують однозначної відповіді «так» чи «ні»). Зазвичай алгоритм будується на дихотомічній системі, оскільки перехід від однієї операції (дії) до іншої здійснюється на підставі двоєдиного вибору. Такі алгоритми називають дихотомічними, двочленними, бінарно-альтернативними [10, с. 246].

5. Алгоритм передбачає певну шаблонізацію кримінально-правових оцінок, суворо визначений порядок дій / операцій, поширюється на невизначене коло подібних випадків, дозволяє розпізнати, до якого класу, виду, категорії належить об'єкт пізнання, передбачає найбільш раціональну послідовність розумових операцій щодо кримінально-правової оцінки вчиненого.

Наведене дає підставу зазначити, що кваліфікація у кримінальному праві характеризується системою алгоритмів та правил, які структурно об'єднані одне з одним і покликані забезпечити правильну кримінально-правову оцінку кримінально значущого діяння. Безперечно, кваліфікація окремих категорій кримінальних правопорушень, діянь, що не є кримінально протиправними, проте мають кримінально-правове значення, та видів посткримінальної поведінки особи має специфіку, проте без загального (загальні алгоритми та правила кримінально-правової оцінки вчиненого) не може існувати спеціальне.

\section{Jimepamypa}

1. Академічний тлумачний словник української мови (1970-1980). URL: http://sum.in.ua/ (дата звернення: 01.06.2021).

2. Шилов В.В. Удивительная история информатики и автоматики. Москва : ЭНАС-Книга, 2013. $216 \mathrm{c}$.

3. Большой экономический словарь. URL: https://big economic dictionary.academic.ru $/ 1253 / \%$ D0 $\% 90 \%$ D0 \% 9B $\%$ D0 \% $93 \%$ D0 \% 9E $\%$ D0 $\%$ A0\% D0\% 98\% D0\% A2\% D0\% 9C (дата звернення: 01.06.2021).
4. Дядькин Д.С. Теоретические основы назначения уголовного наказания: алгоритмический подход. Санкт-Петербург : Юрид. центр «Пресс», 2006. 510 с.

5. Заде Л. Понятие лингвистической переменной и его применение к принятию приближенных решений. Москва : Мир, 1976. 167 с.

6. Ус О.В. Кваліфікація у кримінальному праві України : дис. ... докт. юрид. наук: 12.00.08. Харків, 2020.485 c.

7. Андреев И.В. Теоретико-правовые основы квалификации преступлений : дис. ... канд. юрид. наук: 12.00.08. Тюмень, 2000. 204 с.

8. Никонов В.А. Практикум по научным основам квалификации преступлений : учебное пособие. Тюмень : Юрид. ин-т МВД России, 1996. 72 с.

9. Ус О.В. Теорія та практика кримінально-правової кваліфікації : лекції. Харків : Право, 2018. 368 с.

10. Управление, информация, интеллект / под ред. А.И. Берг и др. Москва : Мысль, 1976. 383 с.

\section{Анотація}

Ус О.В. Алгоритми кваліфікації у кримінальному праві. - Стаття.

Стаття присвячена дослідженню алгоритмів кваліфікації у кримінальному праві. 3'ясовано сутність та зміст алгоритму, алгоритмічних кроків і алгоритмічного процесу. Встановлено, що алгоритм кваліфікації у кримінальному праві - це система дій, модель, програма виконання в певному порядку відповідної послідовності операцій, що визначають процес пошуку результату - встановлення складу кримінально значущого діяння, передбаченого кримінальним законом (кримінальне правопорушення; діяння, що не є кримінально протиправним, проте має кримінально-правове значення; посткримінальна поведінка особи).

Доведено, що для вирішення кваліфікаційного завдання алгоритмічний процес як система поступових взаємозумовлених та взаємопов'язаних операцій потребує поступового надання відповідей на питання: «так» чи «ні», що зумовлює подальшу логіку побудови запитань і розв'язання завдання щодо кримінально-правової оцінки кримінально значущого діяння.

Обгрунтовано, що алгоритм кваліфікації у кримінальному праві характеризується низкою особливостей, як-от скінченність, дискретність, визначеність, масовість (загальність), однозначність, результативність.

Досліджено відмежування алгоритмів кваліфікаціі від етапів кваліфікації, що характеризуються сукупністю відносно відокремлених, пов'язаних один з одним періодів кримінально-правової оцінки щодо встановлення тотожності кримінального юридичного факту складу кримінально значущого діяння та закріплення результатів оцінки у правозастосовному акті, а також від правил кваліфікації, що становлять нормативні приписи, загальновизнані доктринальні положення та роз'яснення вищої судової інстанції, якими має керуватися суб'єкт кваліфікації під час обрання кримінально-правової норми для кримінально-правової оцінки кримінально значущого діяння.

Запропоновані загальні вимоги побудови алгоритмів кваліфікації у кримінальному праві.

Ключові слова: алгоритм кваліфікації, кваліфікація у кримінальному праві, кримінально-правова оцінка вчиненого діяння, кримінально значуще діяння, етапи кваліфікації, правила кваліфікації, кримінально-правова норма. 


\section{Summary}

$U s O$. V. Algorithms of qualification in criminal law. - Article.

The article is devoted to the study of qualification algorithms in criminal law. The essence and content of the algorithm, algorithmic steps and algorithmic process are clarified. It is established that the algorithm of qualification in criminal law is a system of actions, model, program of execution in a certain order of the corresponding sequence of operations defining process of search of result - establishment of structure of the criminally significant act provided by the criminal law (criminal offense; an act that is not criminally illegal but has criminal significance; post-criminal behavior of the person).

It is proved that to solve the qualification problem the algorithmic process as a system of gradual interdependent and interconnected operations requires gradual answers to the question: "yes" or "no", which determines the further logic of constructing questions and solving the problem of criminal-legal assessment of a criminally significant act.
It is substantiated that the algorithm of qualification in criminal law is characterized by several features finiteness, discreteness, certainty, mass (generality), unambiguity, efficiency.

The distinction of qualification algorithms from the stages of qualification, characterized by a set of relatively separate, interconnected periods of criminal law assessment to establish the identity of the criminal legal fact of a criminally significant act and consolidate the results of assessment in the law enforcement act, as well as the rules of qualification normative prescriptions, generally recognized doctrinal provisions and explanations of the higher court, which should be followed by the subject of qualification when choosing a criminal law norm for criminal law assessment of a criminally significant act.

The general requirements of construction of algorithms of qualification in criminal law are offered.

Key words: qualification algorithm, qualification in criminal law, criminal-legal assessment of committed act, criminally significant act, stages of qualification, qualification rules, criminal-legal norm. 